\title{
PERLINDUNGAN HUKUM TERHADAP PASIEN BPJS YANG MENGALAMI CACAT FISIK AKIBAT MALPRAKTEK DOKTER
}

\author{
I Wayan Agus Paramartha, I Nyoman Putu Budiartha, I Putu Gede Seputra \\ Fakultas Hukum Universitas Warmadewa Denpasar, Bali- Indonesia \\ agusparamatha98@gmaiI.com, budiarthaputu59@email.com, gamvongputu@email.com
}

\begin{abstract}
Abstrak
Perlunya pemenuhan hak-hak pasien yang berasal dari kewajiban seorang dokter dalam rumah sakit sehingga dirasa perlunya diatur praktik kedokteran dalam suatu undang-undang. Berdasarkan latar belakang tersebut maka dapat dirumuskan tujuan dari penelitian ini adalah untuk mengetahui Tanggung awab Dokter atas mal praktek yang mengakibatkan cacat fisik pada pasien dan untuk mengetahui perlindungan hukum terhadap pasien BPJS yang mengalami cacat fisik akibat mal praktek dokter. Tipe penelitian dalam penulisan ini menggunakan penelitian hukum normatif. Metode yang penulis gunakan dalam pengumpulan banan hukum adalah metode pengamatan dan pencatatan terhadap suatu oahan pustaka yang diperoleh akan dikumpulkan dan disusun dengan sedemikian ru pa. Kesimpul an dari penelitian ini adalah $\mathrm{P}$ ertanggungjawaban seorang dokter bila dalam melakukan penanganan medis telah terbukti dan bisa dibuktikan melakukan tindakan malpraktek maka bentukbentuk hukum an yang bisa diberikan adalah dengan pelepasan izin dari profesi dokter tersebut oleh Majelis Kehormatan Disiplin Kedokteran Indonesia. Namun ketika terdapat sebuah laporan dari pihak korban atau pasien yang dirugikan ke pihak kepolisian dan telah terbukti atau bisa dibuktikan maka dokter tersebut dapat dikenakan hukuman perdata, pidana dan a dministrasi. Perlindun gan hukum terhad ap pasien BPJS yang mengalami cacat fisik akibat mal praktek dokter telah diatur didalam hukum positif yang berlaku di Ind onesia.

Kata Kunci: Perlindungan Hukum, MailPraktek, Pasien BPJS.
\end{abstract}

\begin{abstract}
The need to fulfill patient rights stemming from the obligations of a doctor in a hospital so that it is deemed necessary to regulate medical practice in a law. Based on this background, it can be formulated that the purpose of this study is to determine the responsibility of doctors for malpractice that results in physical disabilities in patients and to determine legal protection for BPJS patients who experience physical disabilities due to malpractice of doctors. The type of research in this paper uses normative legal research. The method that the author uses in collecting legal assistance is the method of observation and recording of a literature review obtained to be collected and arranged in such a way. The conclusion of this study is that if a doctor is responsible for carrying out medical treatment, it has been proven and can be proven that he has committed malpractice, then the forms of punishment that can be given are the release of permission from the medical profession by the Indonesian Medical Discipline Honorary Council. However, when there is a report from the victim or patient who is harmed to the police and it has been proven or can be proven, the doctor can be subject to civil, criminal and administrative penalties. Legal protection for BPJS patients who experience physical disabilities due to malpractice of doctors has been regulated in positive law in force in Indonesia.
\end{abstract}

Keywords: Legal Protection, Practice Mall, BPJS Patients.

\section{PENDAHULUAN}

Praktik kedokteran mencakup tentang hak-hak yang pasien terima, pelayanan mutu serta kepastian dalam hak masyarakat dalam hukum positif Indonesia. Berdasarkan aturan tersebutlah setiap dokter harus melakukan pelayanan secara profesional dan menghindari mal praktek. Adapun definisi malpraktek Menurut J.Guwandi, (1993) yaitu ketidak profesionalan atau kelakuan buruk yang bertentangan dengan etika profesi tersebut khususnya etika kedokteran, jika dilihat dari segi hukum, dapat ditarik kesimpuIan dimana malpraktek dapat terjadi karena Tindakan oleh seorang dokter yang disengaja (intentional) seperti pada misconduct perbuatan buruk tertentu Tindakan Kelalaian yang dilakukan dokter (negligence), ataupun Suatu kurang ahlian atau ketidak kompetenan dan ketidak profesionalan dari seorang dokter yang tidak beralasan profesi dokter dan tenaga Kesehatan memiliki 
etika profesinya tersendiri sehingga jika mereka melakukan tindakan malpraktek maka mereka dapat dituntut dan dims nta pertanggung jawaban secara pidana bila dalam memberikan pelayanan malah merugikan pasien. Salah satu hak yang harus diterima pasien adalah menerima penjelasan dari Rumah Sakit yang dimana penjelasan tersebut berisi informasi yang benar tentang pelayanan dan itu berlaku untuk seluruh rumahsaktbakrumahsakitbakrumahsakitdi desamaupundi kota.

Kesehatan sebagai salah satu kebutuhan pokok manusia selain sandang, papan, pangan dan pendidikan, dan merupakan salah satu hak dasar sosial (the right to health care) (Huijbers, 1982: 101102) dan hak individu (the right of perikemanusian, keseimbangan, manfaat, perlindungan, penghormatan terhadap hak dan kewajiban, keadilan, gender dan non diskriminatif dan norma-norma agama (Pasal 2 UU Nomor 36 Tahun 2009 tentang Kesehatan). Malpraktek (malapraktek) atau malpraktik terdiri dari suku kata mal dan praktik atau praktek. Mal berasal dari kata Yunani, yang berarti buruk. Praktik (Kamus Umum Bahasa Indonesia, Purwadarminta, 1976) atau praktik (Kamus Dewan Bahasa dan Pustaka kementrian Pendidikan Malaysia, 1971) berarti menjalankan perbuatan yang tersebut dalam teori atau menjalankan pekerjaan (profesi). Jadi, malpraktik berarti menjalankan pekerjaan yang buruk kualitasnya, tidak lege artis, tidak tepat. Malpraktik tidak hanya terdapat dalam bidang kedokteran, tetapi juga dalam profesi lain seperti perbankan, pengacara, akuntan publik, dan wartawan. Dengan demikian, malpraktik medik dapat diartikan sebagai kelalaian atau kegagalan seorang dokter atau tenaga medis untuk mempergunakan tingkat keterampilan dan ilmu pengetahuan yang lazim dipergunakan dalam mengobati pasien atau orang cedera menurut ukuran di lingkungan yang sama (Amir \& Hanafiah, 2008). Banyak persoalan malpraktek, atas kesadaran hukum pasien diangkat menjadi masalah pidana. Menurut Maryanti, hal tersebut memberi kesan adanya kesadaran hukum masyarakat terhadap hak-hak kesehatannya (Isfandyarie, 2005).

Nasution, (2005) berpendapat bahwa Dokter beserta tenaga Kesenatan pada kenyataanya baru bisa dikenakan atau bernadapan dengan aturan hukum apabila telan timbul kerugian bagi pihak pasien karena terjadinya atau adanya keal paan dan kelalaian yang dilakukan oleh seorang dokter beserta tenaga medis dalam bentuk Seorang dokter tidak melakukan kewajioannya Pelanggaran kewajiban yang dila bukan dokter Penyebab kerugian pasien Kerugian yang dialami pasien.

Berikut klasifikasi malpraktek Malfeasance melakukan tindakan yang bertentangan atau melanggar dengan hukum Misfeasance melakukan pemilihan tindakan medis dengan tepat akan tetap dilaksanakan dengan salah Nonfeasance Tidak melakukan tindakan medis yang dimana merupakan kewajioan atau keharusan baginya Berbagai upaya sudah dilakukan demi menjamin hak-hak pasien yang dilakukan kepada pasien yang dimana pasien merupakan penerima pelayanan, dokter sebagai orang yang akan pemberi pelayanan, akan tetapi dengan kemajuan ilmu pengetahuan dan dengan berkembangnya teknologi kedokteran tidak berkembang beriringan dengan pembaharuan dan perkembangan hukum positif di Indonesia. Dalam hukum positif negara Indonesia sendiri sudah terdapat beberapa aturan yang mengatur tentang malpraktek, akan tetapi aparat hu kum yang oertugas mengatur terkait penye!enggaraan ataupun terselenggaranya praktik kedokteran dirasa masih belum oisa memadai, sehingga selama ini masih dirasa dimonopoli oleh kebutuhan keoutuhan formal dan lebih berpinak kepada kepentingan yang berpihak pemerintah, sedangkan porsi-porsi untuk profesi masih sangat kurang.

Malpraktek adalah praktek dokter yang salah, lalai atau tidak tepat, dan manyalahi Undangundang atau kode etik profesi kedokteran. Malprektek terjadi dalam hal adanya: kesalahan dalam menjalankan tugas praktek dokter, atau tidak melakukan tugas sebagaimana standar profesi yang telah ditetapkan. Praktek dokter yang menyalahi Undang-undang, termasuk juga didalamnya apabila dokter telah melakukan pelanggaran kode etik, berarti dokter yang melakukan kelalaian atau tidak melaksanakan standa rprofesi kedokteran, maka dapat disebut sebagai malpraktek (Nurdin, 2015). Kasus malpraktik merupakan tindak pidana yang sangat sering terjadi di Indonesia. Malpraktik pada dasarnya adalah tindakan tenaga profesional yang bertentangan dengan standard operating procedure (SOP), kode etik, dan undang-undang yang berlaku, baik disengaja maupun akibat kelalaian yang mengakibatkan kerugian atau kematian pada orang lain (Sibarani, 2017). Bentuk penyelesaian perkara pidana malpraktik dalam putusan perkara Nomor.288/Pid.Sus/2018/PN.NJK., bahwa sudah sepatutnya seorang dokter harus lebih sering mengecek surat ijin praktek serta surat tanda registrasi sebagai dokter untuk menghindari dari paktek kedokteran yang ilegal. Perlunya pengawasan oleh Dinas Kesehatan setempat serta Ikatan Dokter Indonesia (IDI) harus lebih teliti kepada dokter-dokter yang melakukan praktek tanpa memiliki surat ijin praktek serta surat tanda registrasi, dan tindak tegas 
dalam menindak dokter-dokter yang tidak mematuhi etika kedokteran (Darmawan, 2020).

Sehingga berdasarkan hal tersebut penulis bisa menemukan tujuan dari penelitian ini adalah untuk mengetahui tanggung jawab Dokter atas mal pr aktek yang mengakibatkan cacat fisik pada pasien dan Perlindungan hu kum terhadap pasien BPJS yang mengalami cacat fisik akibat ma praktek dokter.

\section{METODE PENELITIAN}

Tipe penelitian yang diguna can dalam penulisan ini merupakan satu penelitian hukum normatif. Sumber yang dipergunakan adalah sumber yang berkaitan dengan perumusan masalah. Adapun sumber bahan hukum yang dipergunakan yaitu Sumber bahan hukum primer yaitu hukum positif di Indonesia dan Sumber bahan hukum seKunder diambil dari buku-buku, be upa literature, karya ilmiah yang berkaitan, hasil penelitian yang berkaitan, lokal karya yang dibuat berkaitan dengan materi penelitian terkait dan peraturan peraturan yang ada hubungannya dengan objek masalah yang nantinya akan diteliti. Metode yang penulis gunakan dalam pengumpulan banan hukum adalah metode pengamatan dan pencatatan terhadap suatu oahan pustaka yang diperoleh akan dikumpulkan dan disusun dengan sedemikian rupa. Selanjutnya diolah dan dianalisis sistematis dengan metode argumentasi nukum berdasarkan logika hu kum deduktif dan induktif. Hasil analisis dari penelitian ini nantinya akan dipaparkan baik secara deskriptif, dengan penuIis berharap bisa dapat menggambarkan secara jelas dan rinci mengenai asas publisitas dan $\mathrm{mp}$ ikasi yuridis, sehingga diharapkan dapatnya diperoleh sebuah gambaran menyeluruh tentang permasala han terkait yang nantinya akan diteliti.

\section{HASIL DAN PEMBAHASAN}

Pertanggu ngjawaban seorang dokter bi la dalam melakukan penanganan medis telah te bukti dan bisa dibuktiKan melakukan tindakan malp aktek maka bentuk-bentuk hukum an yang bisa diberikan adalah dengan pelepasan izin dari profesi dokter tersebut oleh Majelis Kehormatan Disiplin Kedokteran Indonesia. Namun ketika terdapat sebuah laporan dari pi hak koroan atau pasien yang dirugikan ke pihak kepolisian dan telah terbukti atau bisa dibuktikan maka dokter tersebut dapat dikenakan hukuman perdata, pidana dan administrasi. Perlindungan nukum terhadap pasien BPJS yang mengalami cacat fisik akibat mal praktek dokter telah diatur didalam hukum positif yang berlaku di Indonesia.

Dalam memberikan pelayanan terhadap pasien Badan Penyelenggara Jaminan Sosial Kesehatan sering ditemukan yang namanya hak-hak pasien yang harus dipenuhi dan hal tersebut merupakan kewajiban oleh Rumah Sakit. Tetapi jika hak pasien tersebut tidak dipenuhi olen rumah sakit makan dengan kata Iain rumah sakit telah melanggar kewajioannya sehingga merugi kan pasien maka pasien bisa melakukan tuntutan ke rumahsakit tersebut atau melakukan pengaduan kepada pihak kepolisian.

Pada hukum positif Indonesia pertanggungjawaban nukum pidana yang diterima seorang dokter yang bersangkutan dalam KUHPidana yang mencakup tanggung jawab hukum yang ditimbulkan atau disebabkan oleh kesengajaan maupun kelainan, sehingga dalam hal tanggung jawab dokter atas mal praktek yang menyebabkan cacat fisik menurut undang-undang tersebut di atas dapat dikatakan sebagai pertanggungjawaban atas dasar kesalanan, karena seseorang yang dalam hal ini adalah tenaga medis yang dimana harus bertanggung jawab hal tersebut di karenakan tenaga medis yang bersangkutan telah bersalah dimana tenaga medis tersebut melakukan sesuatu yang menyebabkan kerugian pada orang Iain atau pasien.

Berpedoman pada hukum positif Indonesia terdapat sebuah Lembaga Kesehatan yang bemama BPJS dimana dalam hukum tersebut memuat Badan Penyelenggara Jaminan Sosial (BPJS yang merupakan badan hukum yang dibentuk untuk menyelenggarakan program jaminan sosial, salah satunya adalah BPJS Kesehatan yang berfungsi menyelenggarakan program jaminan kesenatan kepada masyarakat. Pelayanan kesehatan yang bisa diberikan pada fasilitas kesehatan yang telah terdaftar dalam melakukan kerjasama dengan Badan Penyelenggara Jaminan Sosial Kesehatan (BPJS Kesehatan) atau pada keadaan tertentu seperti gawat darurat dapat dilakukan oleh fasilitas kesehatan meskipun fasilitas Kesehatan tersebut tidak bekerja sama dengan Badan Penyelenggara Jaminan Sosia Kesenatan (BPJS Kesehatan). Pelayanan kesehatan dalam program Jaminan Kesehatan Nasional diberikan seca ra berjenjang, efektif dan efisien dengan menerapxan prinsip kendali mutu dan kendali biaya.

Badan Penyelenggara Jaminan Sosial Kesehatan yang dimana yang disebut BPJS adalah sebuah badan hukum yang bertujuan menyelenggarakan program jaminan yang berupa jaminan 
kesenatan. Peserta BPJS Kesehatan adaLah selurun penduduk Indonesia yang harus atau diwajibkan menjadi peserta jaminan kesehatan yang dikelola oleh BPJS tidak terkecuali orang asing yang sedang ataupun telah bekerja dengan jangka waktu paling singkat enam bulan di Indonesia dan dengan telan memenuhi syarat berupa membayar iuran tertentu. Perlindungan hukum yang merupakan hak yang harus diperoleh pasien peserta BPJS adalah hak mereka sebagai seorang hak pasien sebenarnya sendiri telah dilindungi dan diatur dalam hukum positif di Indonesia yaitu diantaranya, Undangundang Praktik Kedokteran, Undang-undang Kesehatan dan Undang-undang Rumah Sakit. Seningga jika seorang dokter ataupun rumah sakit tidak memberikan hak yang senarusnya dterima pasien ataupun tidak memenuhi kewaji bannya sehingga melanggar aturan-aturan di atas sehingga bisa dituntut baik pihak dokter ataupun pihakruman sakit. Apabila terjadi keadaan ataupun kejadian di mana pasien mau pun keluarga pasien mendapat kerugan atau menderita kerugian oisa meBaku kan mengadu kan dokter yang bersangxutan atau dokter yang tela h melakukan mal praktek kepada pihak kepolisian, pihak kejaksaan dan dinas kesehatan maupun Majelis Kehormatan Disiplin Kedokteran Indonesia (MKDKI) baik secara tertulis maupun secara lisan dan dapat melakukan gugatan secara perdata maupun gugatan secara pidana ke pengadilan Negeri setempat.

Adapun tuntutan ganti rugi tidak bisa di berlakukan oagi tenaga kesehatan yang sedang melakukan seouahtndakan penyelamatan nyawa atau melakukan upaya pencegahan kecacatan seseorang dalam keadaan darurat. Setiap pasien maupun keluarga pasien merasa dirugikan akibat adanya tindakan malpraktek atau kesalahan yang dilakukan oleh dokter yang bersangkutan dalam menjalankan sebuah standar profesional kedokteran yang bertentangan hukum, maka dalam penyelesaian masalah tersebut dapat diajukan melalui organisasi Ikatan Dokter Indonesia beserta Majelis Kenormatan Disiplin Kedokteran Indonesia (MKDKI) dan juga Majelis Kehormatan Etika Kedokteran juga melalui pengadilan negeri jika terbukti Tindakan pidana dengan menyertai bukti fisik dari korban malpraktek. Untuk itu, jika seorang pasien terdaftar dalam BPJS atau dengan kata Iain merupakan peserta BPJS telah mendapatkan sebuan pelayanan yang tidak sesuai dengan ketentuan standar rumah sakit, maka perlindungan hukum yang oisa didapatkan bagi pasien yang merupakan peserta BPJS adalah bisa menuntut ganti kerugian kepada pinak ruman sakit sebagai penyeIenggara Kesehatan atau tenaga Kesehatan. Selain itu penyelenggara Kesehatan ataupun dokter yang bersangkutan juga dapat atau bisa dikenai nukuman pidana sebagaimana diatur dalam Hu kum positif Indonesia.

\section{SIMPULAN DAN SARAN}

\section{Simpulan}

Pertanggungjawaban yang dapat dilakukan seorang dokter adalah jika dokter tersebut terbukti telah melakukan malpraktek sehingga hukuman yang bisa diberikan berupa pelepasan ijin profesi dokter yang bersangkutan yang dilakukan pihak yang berwenangan yaitu Majelis Kehormatan Kedokteran. Namun bila adanya laporan dari korban ke pihak kepolisian dan dimana laporan tersebut telah nyata terbukti maka dapat dikenakan hukuman perdata, pidana maupun admi nistrasi. Perli ndungan hukum terhadap pasien BPJS yang mengalami cacat fisik akibat mal praktik dokter telah diatur dalam hukum positif Indonesia.

\section{Saran}

Di harapkan kepada pihak penyedia layanan kesehatan seyogyanya tidak memberikan pelayanan yang berbeda terhadap para pasien, baik itu pasien peserta BPJS Kesehatan maupun Pasien Umum. Di harapkan kepada masyarakat sebagai konsumen (pasien) harus lebih selektif da Ham memanami hakhak sebagai pasien BPJS.

\section{DAFTAR PUSTAKA}

Amir, \& Hanafiah, M. Y. (2008). Etika Kedokteran dan Hukum Kesehatan (Cet. 4). Penerbit Buku Kedokteran EGC.

Atmaja, I. D. a G., \& Budiartha, I. N. P. (2018). Teori- Teari Hukum. Setara Press. Malang.

Darmawan, R. (2020). Penegakan Hukum Terhadap Malpraktek Dokter Yang Melakukan Aborsi. El Iqtishadi, Vol. 2. (2).

Hujibers. (1982). Filsafat Hukum. Kanisius. Yogyakarta. 
Isfandyarie, A. (2005). Malpraktek Dan Resiko Medik Dalam Kajian Hukum Pidana. Prestasi Pustaka. Jakarta.

J.Guwandi. (1993). Etika dan Hukum kedokteran. Fakultas kedokteran Universitas Indonesia. Jakarta. Koeswadji, \& Hadianti, H. (2000). Hukum Untuk Perumasakitan. PT.Citra Aditya Bakti. Bandung. Mertokusumo, S. (2003). Mengenai Hukum Suatu Pengantar. Lioerty, Yogyakarta.

Nasution, B. J. (2005). Hukum Kesehatan dan Pertanggungjawaban Dokter. Rhenika Cipta. Jakarta. Nurdin, M. (2015). Perlindungan Hukum Terhadap Pasien Atas Korban Malpraktek Kedokteran. Jurnal Samudra Keadilan, Vol. 1(1).

Sibarani, S. (2017). Aspek Perlindungan Hukum Pasien Korban Malpraktik Dilihat Dari Sudut Pandang Hukum Di Indonesia. Justitia Et Pax, Vol. 33(1).

Yunanto, D. (2009). Hukum Pidana Malpraktik Medik. Yogyakarta. 